\title{
Factors Affecting Peace and Development of African Countries: The Case of Ethiopia
}

\author{
Kiros Abeselom \\ Department of Rural Development and Agricultural Extension, Wolaita Sodo University, Addis Ababa, Ethiopia \\ Email: kiros.abeselom@wsu.edu.et
}

How to cite this paper: Abeselom, K. (2019). Factors Affecting Peace and Development of African Countries: The Case of Ethiopia. Open Journal of Political Science, 9, 50-71.

https://doi.org/10.4236/ojps.2019.91004

Received: September 20, 2018

Accepted: December 26, 2018

Published: December 29, 2018

Copyright $\odot 2019$ by author and Scientific Research Publishing Inc. This work is licensed under the Creative Commons Attribution International License (CC BY 4.0).

http://creativecommons.org/licenses/by/4.0/

\begin{abstract}
This Research Paper would like to analyze and examine the Factors Affecting Development of the African Countries: The Case of Ethiopia. Africa is potentially rich because Africa has inexhaustible or abundant quantity reserves of important natural (mineral) and agricultural as well as human resources. Moreover, $\$ 148$ billion U.S. dollars are drained every year out of the African continent through various corrupt activities. But on the contrary, Africa suffers from food shortage. Africa's annual food import bill of $\$ 35$ billion is estimated to rise to $\$ 110$ billion by 2025 . Therefore, the question is: why the African countries like Nigeria or Ethiopia are so poor that they are dependent on foreign food aid although they are so rich? For instance, Nigeria is Africa's largest economy and Ethiopia alone could feed easily the whole continent of Africa. However, in the reality also Nigeria is dependent on foreign food aid because Nigeria's resource wealth has not yet translated into gains for its people. Therefore, what is behind of this paradox? There are Factors which affect Development of the African countries: The Case of Ethiopia. These are for example: Good Governance, Law \& Order, Responsibility, Accountability, Responsiveness, Transparency, Awareness, Consciousness, Vision/Aim/ Objective, Concern, Fairness, etc. Consequently, lack of implementation of the above mentioned Factors of Development could cause poverty in a country like Ethiopia. Therefore, Change One's Mind or Mentality, i.e. the way of thinking about things is the decisive key Factor of Development of a country like Ethiopia. In order to find out the reasons behind of the paradox situation of the African countries like Ethiopia and/or Nigeria, the author of this Research Paper has applied the following methodologies: 1) Various sources of secondary data like for example historical and present publications were collected and reviewed. 2) Empirical and observation studies were analyzed and reviewed.
\end{abstract}

\section{Keywords}

Factors, Affecting, Development, African Countries, Ethiopia, Good 


\section{Introduction}

\subsection{Background}

This Paper would like to contribute sincerely and openly to critical discussions and debates on real Factors Affecting Development of African Countries: The Case of Ethiopia.

\section{The question is: What is Development?}

Development is Good change, but this is not as straightforward as it sounds. Development is a specified state of growth or advancement. The term "Development" in international context encompasses the need and the means by which to provide better lives for people in poor countries. Although the term "Development" has many meanings, like growth, expansion, progress, advance, change, improvement, maturity, etc. the word "improvement" of better lives for people in poor African countries, the case of Ethiopia is appropriate for this Paper.

However, the other question is, why the African countries like Ethiopia are poor?

But the question is, are the African countries like Ethiopia really poor?

This Research Paper would like to answer these and other questions in the next chapters. Moreover, the objective of this Research Paper is to examine the paradox situation of Africa as an example of Ethiopia but also Nigeria, Democratic Republic of Congo (DRC) because these countries are rich in natu$\mathrm{ral} /$ mineral, agricultural and human resources on one hand but they are poor on the other hand. For instance the DRC is the second largest country in Africa. The DRC covers a land area larger than the combined areas of Spain, France, Germany, Sweden, and Norway with a population about 77 million.

In order to find out scientific facts about the above stated paradox situation of the African countries like Ethiopia, the author of this Research Paper has applied the following methodologies:

1) Various sources of secondary data like for example historical and present publications were collected and reviewed.

2) Empirical and observation studies were analyzed and reviewed.

\subsection{Problem Statement}

The author of this Research Paper would like to present a clear description of the issue: "Factors Affecting Development of African Countries: The Case of Ethiopia" with vision and methods to solve the problems.

However, in order to deliver a clear description of this issue and to have vision and methods to solve the problems, the author of this Research Paper would like to start with the " $5 \mathrm{Ws}$ ", i.e.:

1) Who does the problem affect? 
2) What are the boundaries of the problem?

3) When does the issue occur?

4) Where is the issue occurring?

5) Why is this issue important?

It is obvious that this issue affects the whole continent of Africa but also the Third World Countries.

Therefore, this issue is important because the economic, social, political and environmental problems of the African countries like Ethiopia should be solved in order to improve the living standard of the poor people in the African countries for example in Ethiopia.

However, the question is, why the African countries like Ethiopia are poor?

But are the African countries like Ethiopia really poor?

This Research Paper would like to answer these and other questions in the next chapters.

The author of this Research Paper is convinced that the above-mentioned problems of the African countries for instance of Ethiopia could be solved if some Conditions or Criteria of Development would be fulfilled by the societies of the African countries like of Ethiopia. ${ }^{1}$

However, the most important Factors of Development of a country like Ethiopia are:

- Good Governance,

- Law \& Order,

- Responsibility,

- Accountability,

- Responsiveness,

- Transparency,

- Awareness,

- Consciousness,

- Vision/Aim/Objective,

- Concern,

- Fairness, etc.

But according to the literature, there are different causes of poverty in Africa, i.e. why African ${ }^{2}$ countries for instance Ethiopia can't feed itself?

Although most of the African countries have ample fertile land, plenty of water and generally favourable climate for food production and fastest growing economies, African countries for example Ethiopia couldn't feed themselves so far. ${ }^{3}$

${ }^{1}$ See a list of Factors of Development below (in the Problem Statement section).

${ }^{2}$ Why Africa can't feed itself", Cape Town- "Yet, the region [Sub-Sahara] is the world's most food insecure-not least because its governments don't play their part", Nov 9, 2013: Source: Internet.

${ }^{3}$ The theme of the 2016 meeting is "Connecting Africa's Resources through Digital Transformation": At the World Economic Forum on Africa 2016 which is held currently from 11-13 May 2016 in Kigali, Rwanda, has Prime Minister Hailemariam Desalegn requested foreign technology support for Africa: Source: Ethiopian TV news on 11.05.2016; https://www.weforum.org/events/world-economic-forum-on-africa-2016/: The Sorry Record of Foreign Aid in Africa|Foundation for Economic ...

fee.org/articles/the-sorry-record-of-foreign-aid-in-africa/. 
Therefore, the question is, what are the reasons, why the African countries like Ethiopia couldn't feed themselves although they have all the natural/mineral, agricultural and human sources?

The causes of poverty in Africa for instance in Ethiopia are controversial, i.e. for instance, for the German Federal Foreign Office (Deutsches Auswärtiges Amt), the German International Cooperation ${ }^{4}$ (GIZ) and the United States Agency for International Development (USAID) is "rapid population growth" the cause of poverty in Ethiopia. ${ }^{5}$

As already noted above the German Federal Foreign Office (Deutsches Auswärtiges Amt) and the GIZ argue that rapid population growth in Ethiopia is the obstacle for economic growth and the cause for steady soil erosion. The German Federal Foreign Office said further that also lack of resources is a cause of the structural problems in Ethiopia and such problems remain unresolved despite huge efforts. ${ }^{6}$

Therefore, the question is, what kind of resource lacks Ethiopia that the German Federal Foreign Office (Deutsches Auswärtiges Amt) claims above? Also USAID says: “Ethiopia's economy is dependent on agriculture, and the country's rapidly growing population underscores the need for sustainable and high-quality access to food."7

USAID said further: "Through Feed the Future, USAID enhances food security, increases agricultural productivity, and promotes resilience, especially among vulnerable populations. Ethiopia's economy is dependent on agriculture, which contributes 43 percent of the GDP and 90 percent of exports. However, just five percent of land is irrigated, and crop yields from small farms are below regional averages. Market linkages are weak, and the use of improved seeds, fertilizers and pesticides remains limited."

But the question is, why couldn't be the following big rivers and lakes ${ }^{9}$ in Ethiopia used for irrigation?

Actually Ethiopia is called as a country of "water tower" or "the mother of water", due to its large number of rivers and lakes.

Contrary to the German Federal Foreign Office (Deutsches Auswärtiges Amt)

\footnotetext{
${ }^{4}$ Äthiopien: Seit 1964 ist die Deutsche Gesellschaft für Internationale Zusammenarbeit (GIZ) GmbH im Auftrag des Bundesministeriums für wirtschaftliche Zusammenarbeit und Entwicklung (BMZ) in Äthiopien tätig. Source: Äthiopien-GIZ https://www.giz.de/de/weltweit/336.html.

${ }^{5}$ Source: Wirtschaft Äthiopiens, Stand: März 2013 and GIZ—Äthiopien https://www.giz.de/de/weltweit/; Wirtschaft Äthiopiens, Stand: März 2013 and

https://www.giz.de/de/weltweit/; Source: website: USAID (25.10.2011; 12.09.2012; 18.12.2012; 07.02.2013; 31.01.2014), Last updated: 22.12.2014: Feed the Future Activities in Ethiopia.

${ }^{6}$ Wirtschaft Äthiopiens, Stand: März 2013 and GIZ: Äthiopien—https://www.giz.de/de/weltweit/.

${ }^{7}$ USAID (25.10.2011; 12.09.2012; 18.12.2012; 07.02.2013; 31.01.2014) Last updated: 22.12.2014: Feed the Future Activities in Ethiopia.

${ }^{8}$ USAID: website: October 25, 2011; September 12, 2012; December 18, 2012; February 7, 2013; January 31, 2014, Last updated: December 22, 2014.

${ }^{9}$ The big rivers are: Blue Nile, Awasch, Tekeze, Akobo, Omo Wenz, Genale Wenz, Wabi-Shebele. The big lakes are: Tana Hayk (the source of Blue Nile), Abaya Hayk, Ziway Hayk, Fincha Hayk, Chew Bahir, Abhe, Lake Turkana, Chamo See, Awassa See.
} 
USAID Slomka said that Ethiopia alone could feed easily the whole continent of Africa. ${ }^{10}$ Because Ethiopia is a big country and it has very fertile soil. Ethiopia is 10th largest country $\left(1.133 .380 \mathrm{~km}^{2}\right)$ in Africa but more than three times bigger than Germany $\left(357.000 \mathrm{~km}^{2}\right)$ or as big as France and Spain together.

Calestous Juma said about the fertile land of Ethiopia that [...] Ethiopia has more than 74 million hectares of cultivable land. So far, only 15 million is cultivated. Bringing three million hectares of land into cultivation in the coming four years is a modest step in the country's effort to foster economic transformation and does not represent misguided land allocation. ${ }^{11}$

Moreover, the New York Times report shows that Ethiopia has one of the most fertile lands in the African continent. It has the potential to become the "food basket of the world". ${ }^{12}$

But it is also fact that Ethiopia is not in a position to feed its own citizens let alone to feed the whole citizens of the African continent. Ethiopia is dependency of foreign food aid.

Unfortunately Ethiopia is not the only country in Africa which is dependent on foreign food aid but also other rich African countries like Nigeria (Africa's largest economy $)^{13}$, Democratic Republic of Congo (DRC), etc.

If we take for example the DRC as already described above it is widely considered to be the richest country in the world regarding natural and agricultural resources; its untapped deposits of raw minerals are estimated to be worth in excess of US \$ 24 trillion. ${ }^{14}$

“The Congo [DRC] is the world's largest producer of cobalt ore and a major producer of copper and diamonds. The Congo has $70 \%$ of the world's coltan, a third of its cobalt, more than $30 \%$ of its diamond reserves, and a tenth of its copper. [...] The Mining industry of the Democratic Republic of the Congo is a significant factor in the world's production of cobalt, copper, diamond, tantalum, tin, and gold as well. [...] A combination of such highly sought resources and recent political struggles have made the Central African nation one of the most affected by the illegal exploitation of its resources. [...] Although the DRC is extremely rich in natural resources, this country is politically unstable, i.e. civil war waged." ${ }^{15}$ Currently the DRC "is one of the poorest countries in the world?"16

Therefore, Slomka asks: "Who gets the benefit of the richness of the African continent"? Another question is, what are the causes of this paradox situation of the African countries like Ethiopia, Nigeria, Democratic Republic of Congo (DRC), etc.?

\footnotetext{
${ }^{10}$ Slomka, M. (08.02.2010): Africa Is Not Poor. Mein afrikanisches Tagebuch: Reise durch einen Kontinent im Aufbruch.

${ }^{11}$ Stop Demonising Foreign Investors in Agriculture, They're Not Grabbing Land. In The Ethiopian Herald (p. 5).

${ }^{12} \mathrm{New}$ York Times (2010). Ethiopia Economy Introduction.

${ }^{13}$ Elliott, M. (2015). Nigeria's Resource Wealth Has Not Yet Translated into Gains for Its People.

${ }^{14}$ Source Internet.

${ }^{15}$ Source Internet.

${ }^{16}$ Source: http://www.who.int/bulletin/releases/NFM0316/en/, World Health Organization (WHO) (2015).
} 
The author of this Research Paper argues that the causes of the paradox situation of the African countries have "exogenous" as well as "endogenous" factors. In other words, the African societies like of Ethiopia are to some extent responsible for the poverty for example food insecurity in their countries. Because there is lack of Good Governance, Law \& Order, Responsibility, Accountability, Responsiveness, Transparency, Awareness, Consciousness, Vision/Aim/Objective, Concern, Fairness, etc.

However, there are also external factors affecting Development of the African countries like of Ethiopia, i.e. political, economic, cultural, etc. hegemony, especially of the Western world.

The Economic Commission for Africa said during the 30th Assembly of Heads of State and Government holding from 22-29 January 2018 in the headquarter of the African Union in Addis Ababa, Ethiopia that over \$148 billion U.S. dollars are drained every year out of the African continent through various corrupt activities, representing about 25 percent of Africa's GDP growth. ${ }^{17}$

"The Executive Secretary of the United Nations Economic Commission for Africa (UNECA), Mrs. Vera Songwe, said on Thursday that the money was lost through various fraudulent activities, Songwa addressed the 32nd ordinary session of the Executive Council of the African Union summit in Addis Ababa."18

Consequently, Slomka asks: "Who gets the benefit of the immense richness of the continent?"

Also Volker Seitz said about the paradox of Africa that the continent has abundant resources which are almost unimaginable quantity and it has diverse cultures. He said: Africa is rich: $60 \%$ of world coffee, $70 \%$ of cacao, $50 \%$ of phosphate, $40 \%$ of plastinic come from Africa. The coltan is the rare kind of ore which exists only in Kivu at the border between Democratic Republic of Congo, Burundi and Rwanda/Uganda. Coltan is indispensable for the manufacturing of Mobil telephone, Laptops and steering system of rockets and or missiles and accordingly it is precious.

Moreover, Africa has rich treasures of diamond, sapphire, (...), gold, petroleum, natural gas and last but not least roses (flowers) should be mentioned. Seitz said further that Africa has bad governance and it is mismanaged. The permanent receive of charity suffocates every initiative for self-help because "Foreign Development Aid" cements the dependency or immaturity of Africa. ${ }^{19}$

In addition to the above quoted facts the World Bank had published its report on October 24, 2012 about the capacity of the African continent under the title: "Africa Can Feed Itself, Earn Billions, and Avoid Food Crises by Unblocking Regional Food Trade" as follows: "A new World Bank report says that Africa's farmers can potentially grow enough food to feed the continent and avert future food crises if countries remove cross-border restrictions on the food trade within

\footnotetext{
${ }^{17}$ Source: www.africanews.com/2018/.../fight-against-corruption-takes-center-stage-at-african-u. ${ }^{18}$ Songwe, V. (2018): [Africa's] "money was lost through various fraudulent activities".

${ }^{19}$ Seitz, V. (2011): Afrika wird arm regiert oder wie man Afrika helfen kann. Originalausgabe 2009, Deutscher Taschenbuch Verlag München, 5, aktualisierte und erweiterte Auflage.
} 
the region. According to the [World] Bank, the African continent would also generate an extra US $\$ 20$ billion in yearly earnings if African leaders can agree to dismantle trade barriers that blunt more regional dynamism. The report was released on the eve of an African Union (AU) ministerial summit in Addis Ababa on agriculture and trade." ${ }^{20}$

But the question is, why the World Bank has released a report about the potential capacity of the African continent just now (in 2012)? Was the potential capacity of the continent really new for the World Bank up to 2012?

Fact is, the World Bank was established in 1944 and therefore, the World Bank should know about the potential capacity of the African continent before October 24, 2012.

The African continent is not only potential rich but also real. Ellen Johnson Sirleaf, President of Liberia and Nobel Peace Prize Laureate said about the actual capacity of the continent as follows: "Africa loses at least $\$ 18$ billion a year because of conflicts. This is money our continent can ill afford to lose." ${ }^{21}$ According to the Mbeki-led report of the High Level Panel on Illicit

Financial Flows Africa is estimated to have lost in excess of $\$ 1$ trillion over the last 50 years. ${ }^{22}$ This sum is roughly equivalent to all of the official development assistance received by Africa during the same timeframe. Currently, Africa is estimated to be losing more than $\$ 50$ billion annually in IFFs. ${ }^{23}$

"The Mbeki-led report of the High Level Panel on Illicit Financial Flows has carried out investigations across the regions since it was established in February 2012." 24 "Our continent is annually losing more than 50 billion US dollars through illicit financial outflows," remarked Mbeki reporting to the Pan African Parliament yesterday. "Our panel is convinced that Africa's retention of the capital that is generated on the continent and should legitimately be retained in Africa must be an important part of the resources to finance the Post-2015 Development Agenda." 25 "According to this report, the flows relate principally to commercial transactions, tax evasion, criminal activities such as money laundering, and drugs, arms and human trafficking, bribery, corruption and abuse of

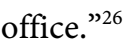

The Economic Commission for Africa said during the 30th Assembly of Heads of State and Government holding from 22-29 January 2018 in the headquarter of the African Union in Addis Ababa, Ethiopia that over $\$ 148$ billion U.S. dollars are drained every year out of the African continent through various corrupt activities, representing about 25 percent of Africa's GDP growth.

\footnotetext{
${ }^{20}$ World Bank (2012). World Bank Report. Washington DC: Press Release.

${ }^{21}$ Sirleaf, E. J. (2012): Africa Loses at Least \$18 Billion a Year Because of Conflicts. https://www.oxfam.org/fr/node/845

${ }^{22}$ Matsilele, T. (2015). Mbeki Panel Ramps up War against Illicit Financial Flows. In Mbeki-led Report.

${ }^{23}$ Kar, D., \& Cartwright-Smith, D. (2010). Illicit Financial Flows (IFFS).

${ }^{24}$ Ibid.

${ }^{25}$ Ibid.

${ }^{26}$ Ibid.
} 
Consequently, Slomka asks: "Who gets the benefit of the immense richness of the continent?" Also Volker Seitz said about the paradox of Africa that the continent has abundant resources which are almost unimaginable quantity and it has diverse cultures. He said: Africa is rich: $60 \%$ of world coffee, $70 \%$ of cacao, $50 \%$ of phosphate, $40 \%$ of plastinic come from Africa. The coltan is the rarekind of ore which exists only in Kivu at the border between Democratic Republic of Congo, Burundi and Rwanda/Uganda. Coltan is indispensable for the manufacturing of Mobil telephone, Laptops and steering system of rockets and or missiles and accordingly it is precious. Moreover, Africa has rich treasures of diamond, sapphire, (...), gold, petroleum, natural gas and last but not least roses (flowers) should be mentioned. Seitz said further that Africa has bad governance and it is mismanaged. The permanent receive of charity suffocates every initiative for self-help because "Foreign Development Aid" cements the dependency or immaturity of Africa. ${ }^{27}$

In addition to the above quoted facts the World Bank had published its report on October 24, 2012 about the capacity of the African continent under the title: "Africa Can Feed Itself, Earn Billions, and Avoid Food Crises by Unblocking Regional Food Trade" as follows: "A new World Bank report says that Africa's farmers can potentially grow enough food to feed the continent and avert future food crises if countries remove cross-border restrictions on the food trade within the region. According to the [World] Bank, the African continent would also generate an extra US $\$ 20$ billion in yearly earnings if African leaders can agree to dismantle trade barriers that blunt more regional dynamism. The report was released on the eve of an African Union (AU) ministerial summit in Addis Ababa on agriculture and trade." 28

But the question is, why the World Bank has released a report about the potential capacity of the African continent just now (in 2012)? Was the potential capacity of the continent really new for the World Bank up to 2012?

Fact is, the World Bank was established in 1944 and therefore, the World Bank should know about the potential capacity of the African continent before October 24, 2012.

The African continent is not only potential rich but also real. Ellen Johnson Sirleaf, President of Liberia and Nobel Peace Prize Laureate said about the actual capacity of the continent as follows: "Africa loses at least $\$ 18$ billion a year because of conflicts. This is money our continent can ill afford to lose."29 According to the Mbeki-led report of the High Level Panel on Illicit Financial Flows Africa is estimated to have lost in excess of $\$ 1$ trillion over the last 50 years. ${ }^{30}$ This sum is roughly equivalent to all of the official development assistance received by Africa during the same timeframe. Currently, Africa is estimated to be

\footnotetext{
${ }^{27}$ Seitz, V. (2011). ibid.

${ }^{28}$ World Bank (2012). ibid.

${ }^{29}$ Sirleaf, E. J. (2012). ibid.

${ }^{30}$ Matsilele, T. (2015). ibid.
} 
losing more than $\$ 50$ billion annually in IFFs. ${ }^{31}$

"The Mbeki-led report of the High Level Panel on Illicit Financial Flows has carried out investigations across the regions since it was established in February 2012." "32 "Our continent is annually losing more than 50 billion US dollars through illicit financial outflows," remarked Mbeki reporting to the Pan African Parliament yesterday. "Our panel is convinced that Africa's retention of the capital that is generated on the continent and should legitimately be retained in Africa must be an important part of the resources to finance the Post-2015 Development Agenda." "According to this report, the flows relate principally to commercial transactions, tax evasion, criminal activities such as money laundering, and drugs, arms and human trafficking, bribery, corruption and abuse of office." ${ }^{34}$

Also the Economic Commission for Africa said during the 30th Assembly of Heads of State and Government holding from 22-29 January 2018 in the headquarter of the African Union in Addis Ababa, Ethiopia that over $\$ 148$ billion U.S. dollars are drained every year out of the African continent through various corrupt activities, representing about 25 percent of Africa's GDP growth. ${ }^{35}$

"The Executive Secretary of the United Nations Economic Commission for Africa (UNECA), Mrs. Vera Songwe, said on Thursday that the money was lost through various fraudulent activities, Songwa addressed the 32nd ordinary session of the Executive Council of the African Union summit in Addis Ababa." ${ }^{36}$

Therefore, the answer of the above question: Why the African countries like Ethiopia are poor?

African countries like Ethiopia are actual poor, because they couldn't feed themselves, i.e. they are dependent on foreign food aid. Africa suffers from food shortage. “Africa's annual food import bill of $\$ 35$ billion [is], estimated to rise to $\$ 110$ billion by 2025 .

Yes, many African countries like Ethiopia suffer from food shortage. "Africa's annual food import bill of $\$ 35$ billion [is], estimated to rise to $\$ 110$ billion by 2025, [that] weakens African economies, decimates its agriculture and exports jobs from the continent.

Africa's annual food import bill of $\$ 35$ billion is just about the same amount it needs to close its power deficit." ${ }^{37}$

Africa is poor, despite all the inexhaustible or abundant quantity reserves of important natural/mineral and agricultural resources.

Why? Because: Lack of the most important Factors of Development like for 
example:

- Good Governance,

- Law \& Order,

- Responsibility,

- Accountability,

- Responsiveness,

- Transparency,

- Awareness,

- Consciousness,

- Vision/Aim/Objective,

- Concern,

- Fairness, etc.

The answer of the other question: Are the African countries like Ethiopia really poor?

The answer is No.

African countries like Ethiopia are potentially rich because Africa has almost inexhaustible or abundant quantity reserves of important natural/mineral and agricultural resources. As already stated above, over $\$ 148$ billion U.S. dollars are drained every year out of the African continent through various corrupt activities.

According to Slomka, Ethiopia alone could feed easily the whole continent of Africa. ${ }^{38}$ Because Ethiopia is a big and very fertile land. Ethiopia is 10th largest country $\left(1.133 .380 \mathrm{~km}^{2}\right)$ in Africa but more than three times bigger than Germany $\left(357.000 \mathrm{~km}^{2}\right)$ or as big as France and Spain together.

Also Calestous Juma said about the fertile land of Ethiopia that [...] Ethiopia has more than 74 million hectares of cultivable land. So far, only 15 million is cultivated. Bringing three million hectares of land into cultivation in the coming four years is a modest step in the country's effort to foster economic transformation and does not represent misguided land allocation. ${ }^{39}$

Moreover, the New York Times report shows that Ethiopia has one of the most fertile lands in the African continent. It has the potential to become the "food basket of the world". 40

But it is also fact that Ethiopia is not in a position to feed its own citizens let alone to feed the whole citizens of the African continent. Ethiopia is dependency of foreign food aid.

Unfortunately Ethiopia is not the only country in Africa which is dependent on foreign food aid but also other rich African countries like Nigeria (Africa's largest economy) $)^{41}$, Democratic Republic of Congo (DRC), etc.

If we take for example the DRC as already described above it is widely consi- 
dered to be the richest country in the world regarding natural and agricultural resources; its untapped deposits of raw minerals are estimated to be worth in excess of US \$ 24 trillion. ${ }^{42}$

"The Congo [DRC] is the world's largest producer of cobalt ore and a major producer of copper and diamonds. The Congo has $70 \%$ of the world's coltan, a third of its cobalt, more than $30 \%$ of its diamond reserves, and a tenth of its copper. [...] The Mining industry of the Democratic Republic of the Congo is a significant factor in the world's production of cobalt, copper, diamond, tantalum, tin, and gold as well. [...] A combination of such highly sought resources and recent political struggles have made the Central African nation one of the most affected by the illegal exploitation of its resources. [...] Although the DRC is extremely rich in natural resources, this country is politically unstable, i.e. civil war waged." ${ }^{43}$ Currently the DRC "is one of the poorest countries in the world?" ${ }^{4}$

Therefore, Slomka asks: "Who gets the benefit of the richness of the African continent"? Another question is, what are the causes of this paradox situation of the African countries like Ethiopia, Nigeria, Democratic Republic of Congo (DRC), etc.?

However, the author of this Research Paper argues that the causes of the paradox situation of the African countries have "exogenous" as well as "endogenous" factors. In other words, the African societies like of Ethiopia are to some extent responsible for the poverty for example food insecurity in their countries.

Because there is lack of implementation or practising the following characters and behaviours among the peoples or societies for example of the African countries like Ethiopia but they can be Factors of Development.

These are for example:

- Fairness,

- Justice,

- Equity (Fairness),

- Trust (Confidence,

- Reliance), Transparent,

- Honesty (Sincerity),

- Openness (Sincerity),

- Discipline,

- Responsibility (Charge),

- Accountability,

- Tolerance,

- Peace,

- Common Understanding and Common Aim among the society of a country, etc. But there are also external factors affecting Development of the African

\footnotetext{
${ }^{42}$ Source Internet.

${ }^{43}$ Source Internet.

${ }^{44}$ Source: http://www.who.int/bulletin/releases/NFM0316/en/, ibid.
} 
countries like of Ethiopia, i.e. political, economic, cultural, etc. hegemony, especially of the Western world.

However, according to USAID ${ }^{45}$, German Federal Foreign Office (Deutsches Auswärtiges $\mathrm{Amt}^{46}$ ) and the $\mathrm{GIZ}^{47}$ "rapid population growth" is the cause of poverty and environmental problems, i.e. for instance for soil erosion and hindrance for economic growth in Ethiopia. ${ }^{48}$

But the question is: Where does the "rapid population growth" or population size of Ethiopia come from without any infrastructure to conduct population census or institutions like Municipality or districts who can register:

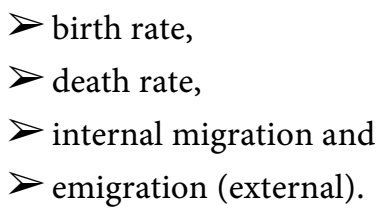

But fact is the Ethiopian government had announced on 4th August 2016 to launch nationwide vital events registration system in Ethiopia for the first time in the history of the country. ${ }^{49}$

The fact that there is no evidence for the arguments of USAID, German Federal Foreign Office and GIZ that "rapid population growth" in Ethiopia is the hindrance for economic growth and the cause of soil erosion, the author of this Research Paper would like to discuss about the real causes of these and other problems in Ethiopia in this Research Paper.

Anyway, the above-mentioned unproven hypothesis of "rapid population growth negative impacts" is advocated also by many academicians and/or scholars and Non-Governmental international Organizations like for example the United Nations Fund for Population Activities (UNFPA), World Bank, German Foundation for World Population (DSW), as well as many mass media especially in the Western world etc.

However, history tells us that debates and discussions on population growth and its negative impacts on economic and social developments have started officially or academically since the publication of the "Essay on Population Growth" in 1798 by Thomas Robert Malthus [1766-1834]. He had published his Essay on Population Growth in 1798. In his Essay Malthus argued that since food production can increase at only arithmetic rate (arithmetic progression) whereas populations tend to grow at geometric rate (geometric progression), the number of people would increase faster than the food supply." He warned that

\footnotetext{
${ }^{45}$ Source: "Evolution of USAID Development Priorities in Ethiopia"-US Agency for ... https://www.usaid.gov/...

${ }^{46}$ Deutsches Auswärtige Amt (2018):

https://www.auswaertiges-amt.de/de/aussenpolitik/laender/aethiopien-node/-/209506, Stand: März 2018.

${ }^{47}$ GIZ: Äthiopien. https://www.giz.de/de/weltweit/.

${ }^{48}$ Deutsches Auswärtige Amt/German Federal Foreign Office/(03/2013): Wirtschaft Äthiopiens and GIZ: Äthiopien. https://www.giz.de/de/weltweit/.

${ }^{49}$ Ethiopian Broadcasting Corporation/ETV on 4th August 2016 and "The Ethiopian Herald" newspaper on 5th August 2016, No. 282, page 1 and 2.
} 
"if this growth is not checked, total population would eventually reach a resource limit which would result in decimation of sections of the population by famine, disease, or war."

But fortunately, this scenario of Malthus' hypothesis did not happen either in the United Kingdom (UK) nor in other Western countries because agricultural and industrial revolutions had solved the economic and social problems of these countries.

However, followers of Malthus, i.e. the Neo-Malthusians say that the hypothesis of Malthus happens in the Third World Countries today. The Neo-Malthusians try to bring extreme situations as an evidence for their hypothesis, for instance, the famine in Ethiopia in 1984/85, droughts and other environmental problems.

Therefore, the hypothesis of Malthusians and Neo-Malthusians is even today controversial. However, there are international scholars which are supported by facts argue contrary to the Malthusians and Neo-Malthusians.

Contrary to the hypotheses of the German Federal Foreign Office (Deutsches Auswärtiges Amt), GIZ and USAID which claim that the cause of poverty and environmental problems in Ethiopia is "rapid population growth", as already stated above, Slomka says that Ethiopia alone could feed easily the whole continent of Africa.

Therefore, the question is, who tells us the truth?

Consequently, the researcher of this Paper would like to examine the reality of these controversial discussions and debates on the ground because this issue concerns almost the whole world.

As already stated above, the situation of the African countries as an example of Ethiopia but also Nigeria, Democratic Republic of Congo (DRC) is paradox because these countries are rich in natural/mineral, agricultural and human resources on one hand but they are poor on the other hand.

However, the question is again, what are the causes of poverty in Ethiopia?

The author of this Research Paper would like to answer the question, why the African countries for instance Ethiopia is poor despite its huge natural/mineral, agricultural and human resources as follows:

Firstly, as already discussed above a society of a country like Ethiopia needs “Development Factors" like for example:

- Awareness,

- Consciousness,

- Vision/Aim/Objective,

- Moral-Ethics,

- Honesty,

- Openness (Sincerity),

- Justice, etc.

The author of this Research Paper has firsthand experiences of the daily happenings (occurrences) in Ethiopia because he works in different regions and 
places of Ethiopia with different people and different professionals like academicians at the universities ${ }^{50}$. He has gathered empirical and observation studies about the Ethiopian society and its mentality, i.e. the way of thinking about things.

For example, the quality of the education system at the Ethiopian universities is very poor, due to lack of good governance (management, planning, organizing, coordinating resources).

Also lack of motivation of teachers, lack of teaching-learning facilities (materials), lack of follow up or take care of students by staffs of their departments, etc.

Moreover, the teaching method of "power point" (presentation with slides) for under graduate students (from 1st - 3rd year) is not appropriate to teach and learn methods because the students are not involved directly in the presentation and they are not able to catch the whole presentation which takes about two hours. In other words they can't concentrate on the whole presentation.

In addition, most of the students at the Ethiopian universities do not have good educational background. That is why the majority of the students cheat and copy during all the tests and examinations. Some of the students couldn't get even a pass mark without cheating and copying. In other words they do not know even very simple words or terms of their major subjects.

Therefore, responsibilities in the Ethiopian Ministry of Education, in the Ethiopian Schools and Universities (top management, colleges and or faculties, departments and teacher staffs) are "killing" the generations in Ethiopia. However, there are very few teachers (lecturers) who didn't yet surrender or resign to fight against such system. Some colleagues (lecturers) are treated by the students and also by other colleagues as "enemies" when they fulfill their duties, i.e. when they control the attendance list of the students, the handouts, course outlines, when they ask the students about general knowledge, when they control the students during examination from cheating, etc. Such colleagues who fulfill their duties will be "punished" by the students when the students evaluate the lectures at the end of every semester with low or bad marks. These low or bad marks harm the colleagues when they apply for academic promotion and or scholarship. Therefore, most of the lectures do not want to control the students whatever the students do.

In addition to the above-mentioned irresponsibility of some colleagues at the Ethiopian universities, the author of this Paper has observed another problem which "kills" the nation or the society as a whole, i.e. corruption. Corruption is in the Ethiopian society subtly or unconscious adopted in different levels and degrees. However, colleagues at the universities should be an example or a model for other groups of the society. But unfortunately, some colleagues at the universities ignore such responsibility. For instance, some colleagues consider money

\footnotetext{
${ }^{50}$ Abeselom, K. (1995): “Der Mythos der Überbevölkerung als Mittel zur Wahrung der bestehenden gesellschaftlichen Strukturen. Die theoretischen Grundlagen der UNO Bevölkerungspolitik: malthusianische und neo-malthusianische Wurzeln", Bonn (Germany).
} 
of the university for a research purpose as a "chance" to get additional income for their private affairs (pocket). Moreover, when some colleagues propose a research project, the proposal may not get an acceptance without bribe. Generally, the system "works" only under the motto "one hand washes the other" (a German proverb).

Secondly, the problems of famine, soil erosion, weak of market linkages, lack of improved seeds, limited fertilizers and pesticides, poor land irrigation, etc. which are claimed by the USAID, German Federal Foreign Office (Deutsches Auswärtiges Amt) and the GIZ, are not caused by "rapid population growth", rather they man-made problems. By the way "rapid population growth" is a symptom of the problems but not the cause the problems.

However, the question is, how serious USAID, German Federal Foreign Office (Deutsches Auswärtiges Amt) and the GIZ argue that famine, soil erosion, weak of market linkages, lack of improved seeds, limited fertilizers and pesticides, poor land irrigation, etc. are caused by "rapid population growth" in Ethiopia?

What is the purpose of such arguments? Do these governmental institutions want to solve really such problems in Ethiopia with birth control?

The discussions and debates about "rapid population growth" or "overpopulation" in the Third World Countries like in Ethiopia serve as a means of preserving the existing economic, social and political structures in the world. ${ }^{50}$

Whatever the purpose of these governmental institutions is, the researcher of this Paper would like to fulfill the research gap on this issue, i.e. the hypothesis of the institutions like USAID, German Federal Foreign Office (Deutsches Auswärtiges Amt) and the GIZ institutions on one hand and the reality on the ground for example in Ethiopia on the other hand which are not discussed sincerely and openly so far.

\subsection{General Objectives}

The General Objectives of this Research Paper are to analyze the controversial discussions and debates about the Factors Affecting Development of the African Countries: The Case of Ethiopia.

The author of this Research Paper is convinced that the economic, social, political and environmental problems of the African countries for instance of Ethiopia could be solved if some

Conditions or Criteria of Development would be fulfilled by the societies of the African countries like of Ethiopia. Some of the important Factors are as already stated above:

- Good Governance,

- Law \& Order,

- Responsibility,

- Accountability,

- Responsiveness,

- Transparency,

- Awareness, 
- Consciousness,

- Vision/Aim/Objective,

- Concern,

- Fairness, etc.

\subsection{Specific Objectives}

As already stated above, African countries like Ethiopia are potentially rich because Africa has inexhaustible or abundant quantity reserves of important natu$\mathrm{ral} / \mathrm{mineral}$ and agricultural as well as human resources. Moreover, $\$ 148$ billion U.S. dollars are drained every year out of the African continent through various corrupt activities, on one hand.

But on the other hand Africa is poor, despite all the unimaginable quantity reserves of important natural/mineral, agricultural and human resources.

It is also fact that Africa suffers from food shortages. As already mentioned-above Africa's annual food import bill of $\$ 35$ billion [is], estimated to rise to $\$ 110$ billion by 2025 , despite the potential of these countries. As already mentioned above, Ethiopia alone could feed easily the whole continent of Africa but in the reality Ethiopia is dependent of foreign food aid. Even Nigeria, Africa's largest economy is dependent on foreign food aid because Nigeria's resource wealth has not yet translated into gains for its people.

Therefore, the Specific Objective of this Research Paper is to examine the Factors Affecting Development of the African Countries: The Case of Ethiopia. In other words, why the African countries like Nigeria or Ethiopia are so poor that they are dependent on foreign food aid although they are so rich?

Therefore, the question is, what is behind of this paradox?

Consequently, the author of this Researcher Paper would like to fulfill the research gap on this issue, i.e. the hypothesis of the institutions like USAID, German Federal Foreign Office (Deutsches Auswärtiges Amt) and the GIZ on one hand and the reality on the ground for example in Ethiopia on the other hand which are not discussed sincerely and openly so far.

\section{Methodology of Data Collection}

In order to find out scientific facts about the above stated paradox situation of the African countries like Ethiopia, the author of this Research Paper has applied the following methodologies:

1) Various sources of secondary data like for example historical and present publications were collected and reviewed.

2) Empirical and observation studies were analyzed and reviewed.

3) The author of this Research Paper has firsthand experiences of the daily happenings (occurrences) in Ethiopia because he works in different regions and places of Ethiopia with different people and different professionals like academicians at the universities ${ }^{51}$. He has gathered empirical and observation

${ }^{51}$ These empirical studies, observations and experiences are gathered by the author of this Research Paper from three (3) Ethiopian universities (from 2013-2018). 
studies about the Ethiopian society and its mentality, i.e. the way of thinking about things.

\section{Research Questions}

What are the causes of poverty in Africa for instance in Ethiopia? Why can't Africa feed itself?

Why can't Ethiopia feed itself?

Is "rapid population growth" the cause of famine, soil erosion, weak of market linkages, lack of improved seeds, limited fertilizers and pesticides, poor land irrigation, etc. are caused by "rapid population growth" in Ethiopia that USAID, German Federal Foreign Office (Deutsches Auswärtiges Amt) and the GIZ claim?

Consequently, the other question is, why the African countries like Ethiopia are poor?

But the question is, are the African countries like Ethiopia really poor?

This Research Paper would like to answer this question with No and Yes.

As already discussed above one answer of the above question is No, because Africa is potentially very rich as experts certify the richness of the African continent. For example, Marietta Slomka said that Africa is not poor, because Africa has breath-taking incredible landscape, almost inexhaustible important reserves of natural resources and fertile land (fertile soils).

Therefore, the question is, why foreign aid fails in Africa for example in Ethiopia although thousands of Governmental and Non-Governmental Organizations are engaged in Ethiopia since about 60 years?

According to Owen Barder there are about 3800 [Non-Governmental Organizations] NGOs in Addis, the capital city of Ethiopia. ${ }^{52}$

But the Ethiopian Authority for Early Warning Disaster Risk Monitoring and Response said that in the year 2011 there were about 2000 international and local Relief and Development Aid Organizations in Ethiopia. ${ }^{53}$

How about bureaucracy in Ethiopia to consider as one cause of poverty? Many people characterize Ethiopia in the media as "The Unconquered Nation, [but] Crippled By Bureaucrats". [...] "bureaucracy [in Ethiopia] is crippling and rough."

The author of this Research Paper describes bureaucracy in Ethiopia as a barrier of development and the bureaucrats as an unfriendly or enemy of the people of Ethiopia.

How can a country promote sustainable development if contraband and illegal business, cheating and corruption are considered as legal and business as usual?

If a society of a country does not plan and prepare for its duties, how can we expect progress in a society or a country?

${ }^{52}$ Barder, O. (08.01.2009): “Aid effectiveness, Development, NGOs, Politics-Ethiopia's new civil society law-Owen abroad”, Addis Ababa, source: http://www.owen.org/blog/2086.

${ }^{53}$ Interview by the researcher of this Paper in year 2011 in Addis Ababa (Ethiopia). 
If the people of a country do not have common interest or vision and do not feel as the owner and take responsibility for the property of the public, how can these people expect sustainable development?

How can the people of a country expect development if the resources of the country are not:

- Planned

- Organized and

- Coordinated?

How can such countries or societies compete in a globalization world in which only the strongest can survive or win?

How can a country or a society expect sustainable development if the society of a country does not give value for Time and Job or Work?

How can a country or a society expect peace and development if the people of a country ignore the right of others?

How can a country or society expect sustainable peace and development if some groups in the society are ethnically or tribal narrow minded?

\section{Hypotheses}

As already discussed above, the author of this Research Paper is convinced that a society of a country like Ethiopia needs "Development Factors" like for example:

- Awareness,

- Consciousness,

- Vision/Aim/Objective,

- Moral-Ethics,

- Honesty,

- Openness (Sincerity),

- Justice,

- Tolerance,

- Peace,

- Discipline,

- Law \& Order,

- Equity (Fairness),

- Trust (Confidence),

- Reliance),

- Transparency,

- Concern,

- Good Governance,

- Responsibility,

- Accountability,

- Responsiveness,

- Exercising leadership,

- Ownership feeling on Public Property,

- Impartiality, 
- Common Understanding and Common Aim among the society of a country,

- Common Interest,

- Integrity,

- Planning, Organization, Coordinating; Cooperation,

- Saving and Conserving all types of Resources of the country,

- Manage or Keep and Use these Resources Properly,

- Keep and Protect all types of Resources from Wastage, etc.

Moreover, Moral-Ethics, Honesty, Openness (Sincerity) are indispensible Factors of Development for a country like Ethiopia. ${ }^{54}$

Therefore, lack of implementation or practising the above-mentioned Factors of Development could cause poverty in a country like Ethiopia.

However, Change One's Mind or Mentality, i.e. the way of thinking about things is the decisive key Factor of Development of a country like Ethiopia.

Let us take examples of developed countries in Europe for example Germany, Sweden, Norway, Denmark and in South East Asia like Japan, Singapur, Malaysia, South Korea, China, etc.

The author of this Research Paper believes and argues that these developed countries pursue or follow their philosophy which contains:

discipline, Law \& Order, integrity,

Common Interest, love to own country,

Ownership feeling on Public Property, optimistic,

vision, plan, organization, coordination practising from kindergarten and onwards, i.e. everyday and the whole life.

As already discussed above, the author of this Research Paper argues that if the people of a country do not have common interest or vision and do not feel as the owner and take responsibility for the property of the public, how can these people expect sustainable development.

The people of a country shouldn't expect development if the resources of the country are not:

- Planned

- Organized and

- Coordinated.

Such countries or societies can't compete in a globalization world in which only the strongest can survive or win.

A country or a society shouldn't expect sustainable development if the society of a country does not give value for Time and Job or Work.

A country or a society shouldn't expect peace and development if the people of a country ignore the right of others.

A country or society shouldn't expect sustainable peace and development if some groups in the society are ethnically or tribal narrow minded.

${ }^{54}$ If the people of a society pretend or act like the Ahmaric Saying "Keanget belay" - this means: above the neck-or "Leysmula"-this means: only for show-development can't be achieved. This is the opinion of the author of this Paper. 


\section{Conclusion}

The researcher of this Paper would like to conclude his research as follows:

Firstly, African countries like Ethiopia are actually poor, because they couldn't feed themselves, i.e. they are dependent on foreign food aid. Africa suffers from food shortage. "Africa’s annual food import bill of $\$ 35$ billion [is], estimated to rise to $\$ 110$ billion by 2025 ."

Secondly, African countries like Ethiopia are potentially rich because Africa has almost inexhaustible or abundant quantity reserves of important natu$\mathrm{ral} / \mathrm{mineral}$ and agricultural resources. As already stated above, over $\$ 148$ billion U.S. dollars are drained every year out of the African continent through various corrupt activities.

According to Slomka, Ethiopia alone could feed easily the whole continent of Africa. Because Ethiopia is a big and very fertile land. Ethiopia is the 10th largest country $\left(1.133 .380 \mathrm{~km}^{2}\right)$ in Africa but more than three times bigger than Germany $\left(357.000 \mathrm{~km}^{2}\right)$ or as big as France and Spain together.

However, "Factors of Development" like for example: Awareness, Consciousness, Vision/Aim/Objective, Moral-Ethics, Honesty, Openness (Sincerity), Justice, Tolerance, Peace, Discipline, Law \& Order, Equity (Fairness), Trust (Confidence), Reliance, Transparency, Concern, Good Governance, Law \& Order, Responsibility, Accountability, Responsiveness, Exercising leadership, Ownership feeling on public property, Impartiality, Common Understanding and Common Aim among the society of a country, Common Interest, Integrity, Organization, Planning, Coordinating; Cooperation, Save and conserve all types of resources of the country are not yet implemented or exercising by the African societies for example Ethiopian society.

But the most important Factors of Development of a country like Ethiopia are Good Governance, Law \& Order, Responsibility, Accountability, Responsiveness, Transparency, Awareness, Consciousness, Vision/Aim/Objective, Concern, Fairness, etc.

Consequently, lack of implementation of the above mentioned Factors of Development could cause poverty in a country like Ethiopia.

Therefore, Change One's Mind or Mentality, i.e. the way of thinking about things is the decisive key Factor of Development of a country like Ethiopia.

\section{Recommendations}

The researcher of this Paper would like to recommend the societies of the African countries like Ethiopia that they should Change One's Mind or Mentality, i.e. the way of thinking about things in order to realize the "Factors of Development" which are discussed above.

Therefore, the solution to Change One's Mind or Mentality, i.e. the way of thinking about things is teaching children starting from parents house and kinder garden about the above mentioned "Factors of Development" but especially about: 
- Moral-Ethics,

- Honesty,

- Openness (Sincerity),

- Tolerance, etc.

Because these are the decisive key Factors of Development of a country like Ethiopia. However, the people in a society shouldn't pretend or act like the Ahmaric Saying "Keanget belay" - this means: above the neck-or "Leysmula"-this means: only for show-if the society wants to achieve development.

\section{Acknowledgements}

I would like to give my special thanks to Mrs. Tsegerda Yoseph, Mrs. Genet Mehari, Mrs. Ezgeharia Mehari, Mr. Asmerom Yoseph, Dr. Ralf Müller, Mrs. Lydia Müller and Mr. Fabian Müller for their invaluable supports throughout my study at the university in Germany.

Also my special thanks go to Professor Dr. Guido Hausmann, to Mr. Gerd Jellinghaus and to Mr. Abby Ogbazghi for their continued warm supports in different aspects throughout the time in Germany.

My special thanks go also to Aveling Mao and the Editorial Team of Open Journal of Political Science (OJPS) for their constructive critiques and supports to edit and revise my two Papers. Last but not least I would like to give also special thanks to family Streber for providing me accommodations during my stay in Germany.

\section{Author's Declaration}

Herewith I (Dr. Kiros Abeselom) declare that I am the only author of this manuscript.

\section{Competing Interest}

I (Dr. Kiros Abeselom) the author of this manuscript declare that I do not have any present or potential competing interest or interferes with a person or organization which is involved in financial or other purposes.

\section{Factors Affecting Development of African Countries}

The Case of Ethiopia.

\section{Conflicts of Interest}

The author declares no conflicts of interest regarding the publication of this paper.

\section{References}

Abeselom, K. (1995). Der Mythos der Überbevölkerung als Mittel zur Wahrung der bestehenden gesellschaftlichen Strukturen. Die theoretischen Grundlagen der UNOBevölkerungspolitik: Malthusianische und neo-malthusianische Wurzeln. Bonn (Ger- 
many).

Alfa Shaban, A. R. (21/04). Interviewed President of the African Development Bank $(A f D B)$. Akinwumi Adesina. http://www.africanews.com

Äthiopien-GIZ: Seit 1964 ist die Deutsche Gesellschaft für Internationale Zusammenarbeit (GIZ) GmbH im Auftrag des Bundesministeriums für wirtschaftliche Zusammenarbeit und Entwicklung (BMZ) in Äthiopien tätig.

https://www.giz.de/de/weltweit/336.html

Barder, O. (08.01.2009). Aid Effectiveness, Development, NGOs, Politics-Ethiopia's New Civil Society Law-Owen Abroad. Addis Ababa. http://www.owen.org/blog/2086

Deutsches Auswärtige Amt (2018). https://www.auswaertiges-amt.de/de/aussenpolitik/laender/aethiopien-node/-/209506

Deutsches Auswärtige Amt/German Federal Foreign Office/(03/2013). Wirtschaft Äthiopiens and GIZ: Äthiopien. https://www.giz.de/de/weltweit/

Elliott, M. (2015). Nigeria's Resource Wealth Has Not Yet Translated into Gains for Its People.

Ethiopian Broadcasting Corporation/ETV on 4th August 2016 and "The Ethiopian Herald" Newspaper on 5th August 2016, No. 282, page 1 and 2.

GIZ: Äthiopien. https://www.giz.de/de/weltweit/

Juma, C. (2011). Stop Demonising Foreign Investors in Agriculture, They're Not Grabbing Land. In The Ethiopian Herald (p. 5).

Kar, D., \& Cartwright-Smith, D. (2010). Illicit Financial Flows (IFFS).

Malthus, Th. R. (1798). An Essay on the Principle of Population.

Matsilele, T. (2015). Mbeki Panel Ramps up War against Illicit Financial Flows. In Mbeki-led Report.

New York Times (2010). Ethiopia Economy Introduction.

Seitz, V. (2011). Afrika wird arm regiert oder wie man Afrika helfen kann. Originalausgabe 2009, Deutscher Taschenbuch Verlag München, 5, aktualisierte und erweiterte Auflage.

Sirleaf, E. J. (2012). Africa Loses at Least \$18 Billion a Year Because of Conflicts. https://www.oxfam.org/fr/node/845

Slomka, M. (08.02.2010). Africa Is Not Poor. In Mein afrikanisches Tagebuch: Reise durch einen Kontinent im Aufbruch.

Songwe, V. (2018). [Africa's] "Money Was Lost through Various Fraudulent Activities".

USAID (25.10.2011; 12.09.2012; 18.12.2012; 07.02.2013; 31.01.2014) (2014). Feed the Future Activities in Ethiopia.

Vanguard News (2018). Africa Loses \$148 Billion to Corruption Annually. by Information Nigeria News Feed.

Wirtschaft Äthiopiens, Stand: März 2013 and GIZ_Äthiopien

https://www.giz.de/de/weltweit/; and website: USAID: (25.10.2011; 12.09.2012; 18.12.2012; 07.02.2013; 31.01.2014), Last updated: 22.12.2014: Feed the Future Activities in Ethiopia.

World Bank (2012). World Bank Report. Washington DC: Press Release.

World Economic Forum on Africa (2016). Kigali, Rwanda. Ethiopian TV News on 11.05.2016. https://www.weforum.org/events/world-economic-forum-on-africa-2016/

World Health Organization (WHO) (2015). Currently the DRC Is One of the Poorest Countries in the World. http://www.who.int/bulletin/releases/NFM0316/en/ 